\title{
Spatial Distribution of Sediment Bacterial Communities in Eutrophicated Meiliang Bay: Correlation with Environmental Factors
}

Yu Wan', Jia $\mathrm{He}^{2}$ and Yang Bai ${ }^{3 *}$

${ }^{1}$ College of Resources and Environment, Southwest University, Chongqing, P.R. China

${ }^{2}$ National Research Center for Upper Yangtze Economy, Chongqing Technology and Business University, Chongqing, P.R. China

${ }^{3}$ The Water and Environmental Research Institute, Chongqing Academy of Environmental Science, Chongqing, P.R. China

\begin{abstract}
Bacterial community structure and the effects of several environmental factors on the spatial distribution of bacterial communities were investigated in the sediment of Meiliang Bay in a large, shallow, eutrophic freshwater lake. Water and surface sediment samples were collected at 10 sampling sites on 15 September 2013. Based on cluster analysis of the DGGE banding patterns, there were no significant variations in spatial distribution of bacterial community structure of the 10 sediment samples in the eutrophicated Meiliang Bay. The dendrogram of the bacterial community similarities in the 10 samples revealed that samples grouped into two defined clusters with a $60 \%$ similarity. Analysis of DNA sequences showed that the dominant bacterial groups in the Meiliang Bay belonged to Proteobacteria, Acidobacteria, Cyanobacterium, Planctomycetes, and Verrucomicrobia, which commonly exist in freshwater ecosystems. In addition, some Actinobacteria, Firmicutes, Nitrospirae bacterial groups were also found in the Meiliang Bay. The transformation of nitrogen and phosphorus nutrients in the water and sediments of Meiliang bay influenced on bacterial community in the sediments. Canonical correspondence analysis demonstrated that total nitrogen and total phosphorus in the sediment significantly influenced the bacterial community structure in the sediment of Meiliang Bay.
\end{abstract}

Keywords: Bacterial community; Sediment; Eutrophication; Meiliang Bay

\section{Introduction}

Bacterial communities in the buried sediments represent up to onethird of the earth's biomass, and was responsible for decomposition of organic matter and mineralization of nutrients in freshwater lake sediments. Sediments were the reservoir of nutrients for the water body and the sediment bacteria drive the nutrient interchange between sediment and water which affects the trophic level of the water body [1]. The environmental factors determined the bacterial community structure, which in turn affects community function, and ultimately ecosystem function [2]. Within freshwater environments, investigation of the bacterial community in the sediment could provide important clues to understanding the key influence factor of bacterial community. Thus, it was imperative to understand the bacterial community structure in the sediment.

Lake Taihu, the third largest shallow freshwater lake in China, was located in the delta of the Yangtze River in Eastern China [3]. The lake could be divided into several lake zones with different ecotypes according to spatial differences in physical-chemical conditions and the plankton community structure. The eutrophic region generally was algae-dominated area, and was characterized by the dominance of phytoplankton, high water turbidity, and strong algal blooms [4]. Meiliang Bay was one of the eutrophic regions on the northern part of the lake. The high nutrient load leads to an extremely productive phytoplankton population in this region. Recently, as a result of the deterioration of water quality, the annual algal bloom was almost continuous for half a year especially in the summer and autumn, similar to other shallow lakes in the world, such as Lake Okeechobee in USA [5].

In order to understand the bacterial community structures in the eutrophication aquatic environments, some studies have been performed in Taihu. $\mathrm{Wu}$ et al. reported the spatial distribution of the bacterial community composition in the water column of 6 different eutrophic areas of Lake Taihu and demonstrated that there were significant variations in bacterial community composition between different lakes
[4]. Tang et al. discovered that there was horizontal heterogeneity of organic-aggregate-associated bacterial community composition in the different lake areas of eutrophic freshwater Lake Taihu [6]. Thus, the spatial and temporal variabilities in several environmental parameters, such as nitrogen-associated factors, organic matter, and $\mathrm{pH}$, had been considered to be the key factors driving the change in bacterial community composition $[7,8]$. Bacterial community was considered to be one of the important elements regulating the nutrient release and recycle. However, the detailed information about the primary bacterial community in eutrophic regions during the period of algae bloom and their environmental impact factors was still insufficient.

The important environmental factors had significant effect on the microbial community in sediment had received more and more attention. However, there was little information about the distribution and species composition of the sediment bacterial community in Meiliang Bay during the period of algae bloom, especially little was known about bacterial community structures contribution to the eutrophication lake ecosystem, and which knowledges was very important for better understanding of the benthic ecosystem processes in eutrophic aquatic environments. Whether the changes in microbial assemblages were associated with diverse environmental factors has also not been determined. The aim of our study was to examine the spatial distribution of sediment bacterial community present in

*Corresponding author: Yang Bai, The Water and Environmental Research Institute Chongqing Academy of Environmental Science, Qi Shan Road, Yu Bei District, Chongqing, P. R. China, Tel: 862362769399; E-mail: baiyang0128@126.com

Received October 18, 2017; Accepted November 24, 2017; Published November 28, 2017

Citation: Wan Y, He J, Bai Y (2017) Spatial Distribution of Sediment Bacterial Communities in Eutrophicated Meiliang Bay: Correlation with Environmental Factors. J Aquac Res Development 8: 514. doi: 10.4172/2155-9546.1000514

Copyright: (c) 2017 Wan Y, et al. This is an open-access article distributed under the terms of the Creative Commons Attribution License, which permits unrestricted use, distribution, and reproduction in any medium, provided the original author and source are credited. 
the eutrophication Meiliang Bay of Lake Taihu during the period of algae bloom and to reveal (i) what were the predominant bacterial community members of this eutrophic area and (ii) which environment factors had significantly impact on bacterial community composition in the sediment.

\section{Materials and Methods}

\section{Sampling sites and sample collection}

Lake Taihu was a shallow eutrophic freshwater lake, located in the southeastern part of the delta of the Yangtze River. Meiliang Bay, located in the northern part of Lake Taihu, was one of the most eutrophic areas and was typically an algae-dominated state in Lake Taihu. The water circulation in September driven by wind was from north to south of the Meiliang Bay. Within the lake, we worked at 10 sampling sites in the Meiliang Bay (Figure 1)

Sediment and water samples were collected in Meiliang Bay on 15 Sep 2014. Three replicate sediment cores were collected by using a piston corer from each of the ten sampling sites. Surface sediments $(0-2 \mathrm{~cm})$ were taken by using a slicing disc and transferred into sterile plastic containers, and immediately stored frozen at $-80^{\circ} \mathrm{C}$. The bottom water from the different sampling sites were transported in $1 \mathrm{~L}$ sterile flasks, brought into the laboratory, and stored at $4^{\circ} \mathrm{C}$.

\section{Analysis of physicochemical parameters}

The dissolved oxygen (DO), chlorophyll a (Chl a), Algal Density and $\mathrm{pH}$ of bottom water were measured in situ using a multiparameter water quality sonde (YSI $6600 \mathrm{~V} 2$, USA). The content of total nitrogen (S-TN), ammonium nitrogen $\left(\mathrm{S}-\mathrm{NH}_{4}\right)$, nitrate-nitrite nitrogen $\left(\mathrm{S}-\mathrm{NO}_{\mathrm{x}}\right)$, total phosphorus (S-TP), total organic matter (TOM) in the sediment and the concentration of ammonium $\left(\mathrm{P}-\mathrm{NH}_{4}\right)$, nitrate nitrogen $(\mathrm{P}$ $\mathrm{NO}_{3}$ ) in the pore water were measured in the laboratory according to Haller et al. [9]. Total nitrogen (W-TN), ammonium nitrogen (W-NH $\mathrm{N}_{4}$, nitrate nitrogen $\left(\mathrm{W}-\mathrm{NO}_{3}\right)$, total phosphorus (W-TP), and Chemical Oxygen Demand (COD) of overlying water measurements were conducted as described by Tang et al. [6].

\section{DNA extraction, purification and PCR-DGGE analysis}

Sediment DNA was extracted according to Zhou et al. with slight modifications [10]. Crude DNA extracts were further purified immediately using the Power CleanTM DNA Clean-Up Kit (Mo Bio). Purified DNA was used as template for polymerase chain reaction (PCR) amplification of partial 16S rRNA gene, by using the bacterium-specific primer F341 (5'-CCTACGGGAGGCAGCAG-3') with a $40 \mathrm{bp}$ GC-clamp attached to its 5 ' end, and the universal primer

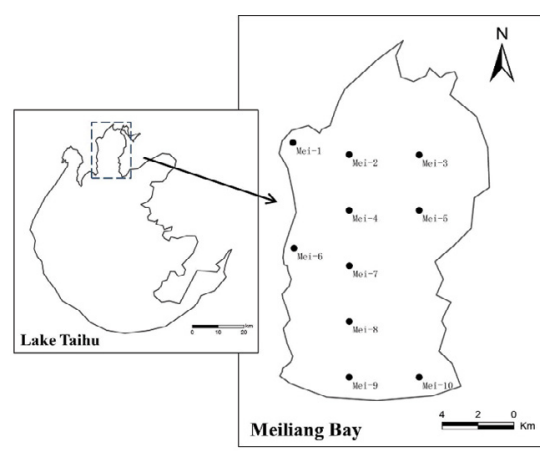

Figure 1: Map of Lake Taihu in China, showing the locations of 10 sampling sites in Meiliang Bay.
R518 (5'-ATTACCGCGGCTGCTGG-3') [11]. The PCR cycling was performed in a thermo cycler under the following conditions: $95^{\circ} \mathrm{C}$ for $5 \mathrm{~min}, 30$ cycles at $94^{\circ} \mathrm{C}$ for $30 \mathrm{~s}, 55^{\circ} \mathrm{C}$ for $45 \mathrm{~s}$ and $72^{\circ} \mathrm{C}$ for $1 \mathrm{~min}$, followed by a final extension at $72^{\circ} \mathrm{C}$ for $10 \mathrm{~min}$.

The DGGE was performed with a DCodeTM Universal system by using $8 \%(\mathrm{wt} / \mathrm{vol}$ ) polyacrylamide gel with a denaturing gradient ranging from 40 to $65 \%$. The same amount of PCR products with 10 samples was loaded, and the gel was run initially at $20 \mathrm{~V}$ for $15 \mathrm{~min}$, and then at $100 \mathrm{~V}$ for $16 \mathrm{~h}$ at $60^{\circ} \mathrm{C}$ in $1 \times \mathrm{TAE}$ buffer. The gel was stained with SYBR Green I solution for $30 \mathrm{~min}$, and photographed with a Gel Doc XRTM system.

A gel documentation system (GelCompar II software, Applied Maths) was employed to evaluate the bacterial community in the different sediment samples, based on a matrix of relation band intensities and a binary matrix according to the presence (1) or absence (0) of bands. Cluster analysis of the DGGE banding patterns obtained from different sediment sampling sites was performed with an unweighted pairwise grouping method with mathematical averages (UPGMA).

\section{Cloning, sequencing and phylogenetic analysis}

Before cloning and sequencing, we examined the bacterial community composition of sediment using denaturing gradient gel electrophoresis (DGGE). The DGGE fingerprints indicated that the bacterial community of 10 sediment samples was very similar, and so we used only one DNA of sediment samples from site Mei-8 in later cloning and sequencing analysis. An approximately $1500 \mathrm{bp}$ fragment of bacterial $16 \mathrm{~S}$ rRNA genes was amplified in a thermocycler using the eubacterial forward primer 27F (5'-AGAGTTTGATCMTGGCTCAG-3') and the universal reverse primer 1492R (5'-GGTTACCTTGTTACGACTT-3') [12]. The PCR cycling was performed under the following conditions: $95^{\circ} \mathrm{C}$ for $5 \mathrm{~min}, 30$ cycles at $94^{\circ} \mathrm{C}$ for $30 \mathrm{~s}, 52^{\circ} \mathrm{C}$ and $72^{\circ} \mathrm{C}$ for $1 \mathrm{~min}$, with an additional $10 \mathrm{~min}$ of final extension at $72^{\circ} \mathrm{C}$. The PCR products were purified immediately with the E.Z.N.A. ${ }^{\circledR}$ Cycle-Pure Kit, and cloned into pMD18-T vector according to the manufacturer's instruction. The ligated DNA was transformed into E. coli TOP10 super competent cells. The randomly chosen clones were reamplified with the PCR program using the primers RV-M and M13-47 that targeted the vector sequences to ignore false-positive clones. Representative clones were sequenced on an ABI PRISM 3730 automated DNA capillary sequencer (Applied Biosystems) by Invitrogen Company (Shanghai, China). Raw sequence data were edited manually using the software BioEdit (version 7.0.9), which generated high-quality reads of 650-750 bases. Sequences with $97 \%$ sequence similarity to any other were treated as a single phylotype. All sequences obtained were checked for potential chimeric sequences using the CHECK_CHIMERA program from the Ribosomal Database Project (http://rdp.cme.msu.edu). Sequences containing no chimera were submitted to a BLAST search (http://www.ncbi.nlm.nih.gov) to find closely related sequences.

\section{Statistics Analyses}

Canonical correspondence analysis (CCA) were used to analyses the relation between sediment bacterial communities and the major environmental variables, and the environmental factors were $\mathrm{pH}, \mathrm{DO}$, $\mathrm{S}-\mathrm{TN}, \mathrm{S}-\mathrm{NH}_{4}, \mathrm{~S}-\mathrm{NO}$, S-TP, S-TOM in sediment and $\mathrm{P}-\mathrm{NO}_{3}, \mathrm{P}-\mathrm{NH}_{4}$ in pore water. The correlation analysis was performed with SPSS 18.0.

\section{Nucleotide sequence accession numbers}

The 16S rRNA gene sequences obtained in the present study were 
Citation: Wan Y, He J, Bai Y (2017) Spatial Distribution of Sediment Bacterial Communities in Eutrophicated Meiliang Bay: Correlation with Environmental Factors. J Aquac Res Development 8: 514. doi: 10.4172/2155-9546.1000514

Page 3 of 6

\begin{tabular}{|c|c|c|c|c|c|c|c|c|c|c|c|}
\hline Variables & Sites & Mei-1 & Mei-2 & Mei-3 & Mei-4 & Mei-5 & Mei-6 & Mei-7 & Mei-8 & Mei-9 & Mei-10 \\
\hline \multirow{10}{*}{ Water } & $\mathrm{pH}$ & 8.62 & 8.84 & 8.77 & 8.75 & 8.18 & 8.48 & 8.53 & 8.55 & 8.49 & 8.43 \\
\hline & $\mathrm{DO}(\mathrm{mg} / \mathrm{L})$ & 9.15 & 9.56 & 8.9 & 9.17 & 7.94 & 8.43 & 8.69 & 8.94 & 8.63 & 8.68 \\
\hline & Algal Density $\left(10^{7}\right.$ cell/L) & 1.26 & 1.16 & 0.62 & 0.92 & 0.63 & 0.60 & 0.98 & 0.78 & 0.86 & 1.03 \\
\hline & Chlorophyll (ug/L) & 7.6 & 8.1 & 4.5 & 6.4 & 4.8 & 4.6 & 7 & 5.7 & 5.5 & 6.7 \\
\hline & $\mathrm{TN}(\mathrm{mg} / \mathrm{L})$ & 1.41 & 1.58 & 0.63 & 0.95 & 0.66 & 0.68 & 1.60 & 0.72 & 0.76 & 1.29 \\
\hline & $\mathrm{TP}(\mathrm{mg} / \mathrm{L})$ & 0.22 & 0.20 & 0.14 & 0.18 & 0.14 & 0.16 & 0.19 & 0.15 & 0.14 & 0.17 \\
\hline & $\mathrm{NH}_{4}^{+}-\mathrm{N}(\mathrm{mg} / \mathrm{L})$ & 0.37 & 0.05 & 0.05 & 0.23 & 0.04 & 0.10 & 0.09 & 0.06 & 0.10 & 0.19 \\
\hline & $\mathrm{NO}_{3}^{-}-\mathrm{N}(\mathrm{mg} / \mathrm{L})$ & 0.23 & 0.07 & 0.04 & 0.25 & 0.06 & 0.29 & 0.12 & 0.14 & 0.20 & 0.33 \\
\hline & TN/TP & 6.56 & 8.10 & 4.65 & 5.42 & 4.77 & 4.32 & 8.62 & 4.79 & 5.45 & 7.49 \\
\hline & $\mathrm{COD}(\mathrm{mg} / \mathrm{L})$ & 8.04 & 7.84 & 5.88 & 7.00 & 6.68 & 6.12 & 6.72 & 8.92 & 5.44 & 8.2 \\
\hline \multirow{2}{*}{ Pore water } & $\mathrm{NH}_{4}{ }^{+}-\mathrm{N}(\mathrm{mg} / \mathrm{L})$ & 1.90 & 3.12 & 2.82 & 2.68 & 3.53 & 2.44 & 3.74 & 2.92 & 2.78 & 3.33 \\
\hline & $\mathrm{NO}_{3}^{-}-\mathrm{N}(\mathrm{mg} / \mathrm{L})$ & 0.07 & 0.07 & 0.07 & 0.07 & 0.08 & 0.07 & 0.08 & 0.07 & 0.07 & 0.07 \\
\hline \multirow{6}{*}{ Sediment } & $\mathrm{TN}(\mathrm{mg} / \mathrm{kg})$ & 789.6 & 1184.4 & 1097.2 & 677.6 & 537.6 & 1181.6 & 1064.3 & 1321.6 & 1097.6 & 1369.2 \\
\hline & TP (mg/kg) & 408.1 & 478.7 & 493.1 & 381.1 & 370.4 & 455.7 & 443.9 & 569.2 & 481.3 & 520.3 \\
\hline & TOM (mg/g) & 19.1 & 20.3 & 19.5 & 18.8 & 17.9 & 16.1 & 12.2 & 15.2 & 13.5 & 18.6 \\
\hline & $\mathrm{NH}_{4}{ }^{+}-\mathrm{N}(\mathrm{mg} / \mathrm{kg})$ & 100.3 & 135.4 & 95.6 & 116.6 & 156.3 & 86.3 & 102.7 & 86.3 & 98.1 & 123.7 \\
\hline & $\mathrm{NO}_{x}^{-}-\mathrm{N}(\mathrm{mg} / \mathrm{kg})$ & 32.7 & 63.2 & 42.1 & 51.3 & 46.7 & 67.6 & 37.3 & 30.3 & 25.7 & 37.3 \\
\hline & TN/TP & 1.94 & 2.47 & 2.23 & 1.78 & 1.45 & 2.59 & 2.40 & 2.32 & 2.28 & 2.63 \\
\hline
\end{tabular}

Table 1: Physico-chemical parameters of the 10 sampling sites for Meiliang Bay of Lake Taihu.

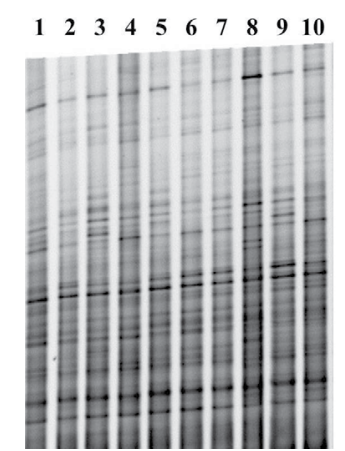

Figure 2: Denaturing gradient gel electrophoresis (DGGE) banding patterns of different sediment samples.

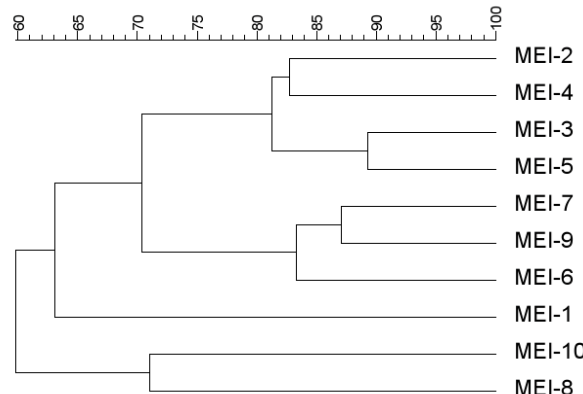

Figure 3: Dendrogram for 10 surface sediment samples in the Meiliang Bay of Lake Taihu.

available in the GenBank database under the accession numbers: KM095136-KM095248.

\section{Results}

\section{Physicochemical properties of the samples}

The physicochemical parameters of bottom water, pore water and sediment of 10 sampling sites in Meiliang Bay were shown in Table 1. The temperature of water was $24.5^{\circ} \mathrm{C}$ in September during the period of algae bloom. In the bottom water of Meiliang bay, the average value of
$\mathrm{pH}, \mathrm{DO}$, algal density, chlorophyll a, TN and TP were $8.56,8.81 \mathrm{mg} / \mathrm{L}$, $0.88 \times 10^{7}$ cell $/ \mathrm{L}, 6.1 \mathrm{ug} / \mathrm{L}, 1.03 \mathrm{mg} / \mathrm{L}$ and $0.17 \mathrm{mg} / \mathrm{L}$, respectively. The concentration of TN, TP, algal density and chlorophyll a were relatively high at the Mei- 1 and Mei- 2 sites. The average value of $\mathrm{NH}_{4}^{+}-\mathrm{N}$ was 0.13 $\mathrm{mg} / \mathrm{L}$, which the highest at the Mei-1 site. The average value of $\mathrm{NO}_{3}^{-}-\mathrm{N}$ was $0.17 \mathrm{mg} / \mathrm{L}$, which the highest at the Mei-10 site. The average value of COD was $7.08 \mathrm{mg} / \mathrm{L}$, which the highest at the Mei- 8 site. The ratios of TN/TP in water varied from 4.32 to 8.62 .

Of the pore water in the Meiliang bay, the average value of $\mathrm{NH}^{4+-} \mathrm{N}$ was $2.93 \mathrm{mg} / \mathrm{L}$, which the highest at the Mei-7 site. The $\mathrm{NO}_{3}$ - $\mathrm{N}$ concentration of each sampling sites were little difference, with an average value of $0.07 \mathrm{mg} / \mathrm{L}$.

In the sediment of Meiliang bay, the average value TN and TP were $1032.1 \mathrm{mg} / \mathrm{kg}$ and $460.2 \mathrm{mg} / \mathrm{kg}$ respectively, which were relatively high at the Mei-10 and Mei- 8 sites, while the lowest all in the Mei- 5 site. The average value of TOM was $17.1 \mathrm{mg} / \mathrm{kg}$, which the highest at the Mei-2 site. The average value of $\mathrm{NH}_{4}^{+}-\mathrm{N}$ was $110.13 \mathrm{mg} / \mathrm{kg}$, which the highest at the Mei-5 site. The average value of $\mathrm{NO}_{\mathrm{x}}--\mathrm{N}$ was $43.42 \mathrm{mg} / \mathrm{kg}$, which the highest at the Mei- 6 site. The ratios of TN/TP in sediment varied from 1.45 to 2.63 .

The correlation analysis showed that DO, Chlorophyll, TN, TP and $\mathrm{NH}_{4}^{+}-\mathrm{N}$ in the water were significantly and positively correlated with the algal density (coefficients between 0.63 and $0.96, \mathrm{p}<0.01$ ) (Table 2).

\section{Cluster analysis of DGGE profiles}

The spatial distribution of the bacterial communities in the sediment samples was evaluated by DGGE analysis (Figure 2). The number of recognized DGGE bands derived from 10 sites varied weakly, with 25 to 33 bands per sample. The band number was the highest at the Mei10 site, while the lowest was at the Mei-1 site (Table 3). The sediment samples of site Mei-1 had the lowest genetic diversity, Mei-10 site had higher genetic diversity.

An unweighted pair-wise grouping method with mathematical averages (UPGMA) dendrogram (Figure 3 ) was constructed from the bacterial DGGE profiles to describe the similarities of the bacterial communities in the different samples. The dendrogram showed that samples were grouped into 2 defined clusters, which the cluster containing only the bacterial communities found in Mei-8 and Mei- 
10 , and another cluster containing the bacterial communities found in the rest of other sampling sites. The dendrogram also revealed that samples were grouped into two defined clusters with a $60 \%$ similarity, which demonstrated that there were no significant variations in spatial distribution of bacterial community structure of the sediment in the Meiliang Bay.

\section{Clone library analyses and phylogenetic analysis of sequences}

In total, 112 non-chimeric partial $16 \mathrm{~S}$ rRNA gene sequences were acquired from the clone libraries from the eutrophicated Meiliang Bay (Table 4). The total sequenced clones in libraries were dominated by Proteobacteria (40.2\%), Acidobacteria (12.5\%), Cyanobacteria (10.7\%), Planctomycetes (8.9\%), Verrucomicrobia (8.9\%), Bacteroidetes (7.1\%), Nitrospirae (5.4\%), Actinobacteria (2.7\%), Firmicutes $(1.8 \%)$, Unclassified bacteria (1.8\%). The Proteobacteria was dominated by Gammaproteobacteria (12.5\%), Betaproteobacteria $(12.5 \%)$, Deltaproteobacteria (11.6\%), Epsilonproteobacteria (1.8\%) and Alphaproteobacteria (1.8\%). Comparison of many sequences from our libraries with those of uncultured or cultured bacteria from GenBank, showed that our sequences most closely resembled those of bacteria inhabiting freshwater, sediments, soils, biofilms and activated sludge (Table 4).

\section{Bacterial community composition in relation to sediment properties}

We prepared a CCA biplot of the DGGE sample (lanes) and the nine environmental variables in Meiliang Bay (Figure 4). The plot demonstrated that TN and TP in sediment played significant roles in the bacterial community composition in the sediment. The eigenvalues

\begin{tabular}{|c|c|c|c|c|c|c|c|}
\hline Variables & \multicolumn{7}{|c|}{ Physicochemical properties } \\
\hline \multirow{2}{*}{ Water } & DO & Chlorophyll & TN & $\mathrm{NH}_{4}^{+}-\mathrm{N}$ & $\mathrm{NO}_{3}-\mathrm{N}$ & TP & COD \\
\hline & $0.66^{* *}$ & $0.96^{* *}$ & $0.88^{* *}$ & $0.63^{* *}$ & 0.20 & $0.89^{*+}$ & $0.53^{*}$ \\
\hline \multirow{2}{*}{ Sediment } & TN & TP & TOM & $\mathrm{NH}_{4}^{+}-\mathrm{N}$ & $\mathrm{NO}_{x}^{-}-\mathrm{N}$ & - & - \\
\hline & 0.04 & -0.05 & 0.21 & 0.14 & -0.19 & - & - \\
\hline \multirow{2}{*}{$\begin{array}{l}\text { Pore } \\
\text { Water }\end{array}$} & $\mathrm{NH}_{4}{ }^{+} \mathrm{N}$ & $\mathrm{NO}_{3}^{-}-\mathrm{N}$ & - & - & - & - & - \\
\hline & -0.17 & 0.35 & - & - & - & - & - \\
\hline
\end{tabular}

Table 2: Correlation analysis among algal density and physicochemical properties.

\begin{tabular}{|l|l|l|l|l|l|l|l|l|l|l|} 
Sites & Mei-1 & Mei-2 & Mei-3 & Mei-4 & Mei-5 & Mei-6 & Mei-7 & Mei-8 & Mei-9 & Mei-10 \\
\hline
\end{tabular}

\begin{tabular}{|l|l|l|l|l|l|l|l|l|l|l|}
\hline Bands & 25 & 26 & 27 & 27 & 26 & 26 & 29 & 32 & 29 & 33 \\
\hline
\end{tabular}

Table 3: Analysis of microbial community diversity in sediment.

\begin{tabular}{|c|c|c|}
\hline Phylogenetic group & No. of clones & Frequency (\%) \\
\hline Alphaproteobacteria & 2 & 1.8 \\
\hline Betaproteobacteria & 14 & 12.5 \\
\hline Gammaproteobacteria & 14 & 12.5 \\
\hline Deltaproteobacteria & 13 & 11.6 \\
\hline Epsilonproteobacteria & 2 & 1.8 \\
\hline Acidobacteria & 14 & 12.5 \\
\hline Actinobacteria & 3 & 2.7 \\
\hline Bacteroidetes & 8 & 7.1 \\
\hline Cyanobacterium & 12 & 10.7 \\
\hline Firmicutes & 2 & 1.8 \\
\hline Nitrospirae & 6 & 5.4 \\
\hline Planctomycetes & 10 & 8.9 \\
\hline Verrucomicrobia & 10 & 8.9 \\
\hline Unclassified & 2 & 1.8 \\
\hline Total & 112 & 100 \\
\hline
\end{tabular}

Table 4: Phylogenetic affiliation of clones constructed with 16S rRNA libraries from sample site Mei-8.

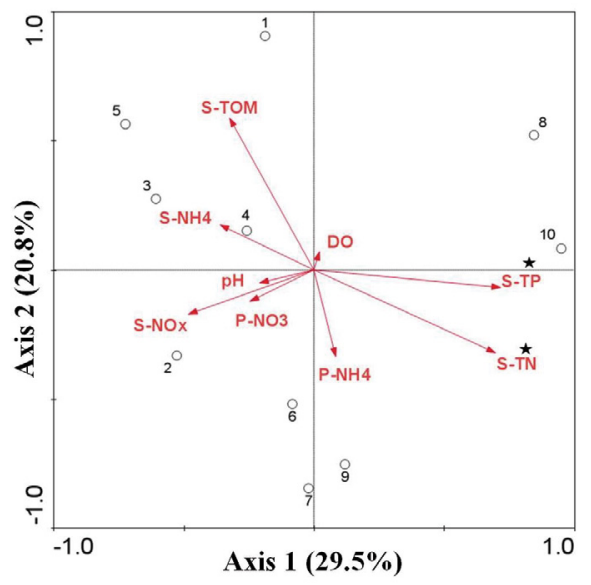

Figure 4: Canonical correspondence analysis (CCA) ordination diagram of bacterial communities associated with 9 environmental variables.

of the first and second axis were 0.295 and 0.208 , respectively, and these two axes explained $50.3 \%$ of the variation in the bacterial community composition of the sediment.

\section{Discussion}

In the present study, the characterization of both water and sediment samples obtained from eutrophic Meiliang Bay offered some valuable information. Firstly, the ratios of TN/TP in water varied from 4.32 to 8.62 (Table 1), which less than 10 [13], indicated that $\mathrm{N}$ was the limit factor for blooming in Meiliang bay. These observations were important for the control of algae bloom in the Meiliang bay, which different eutrophic water systems had same parameters, such as $\mathrm{N}$ was the limit factor in the Lake Daihai in Inner Mongolia of China [14]. Secondly, the concentrations of TN and TP in sediments were 5601841 and 1898-795 times greater than those in the water, with TN/TP ratio of 1.45 to 2.63 (Table 1), demonstrated that the great capacity of sediment to serve as a nutrient reservoir for the water. Thirdly, the positive correlations among $\mathrm{TN}, \mathrm{TP}, \mathrm{NH}_{4}^{+}-\mathrm{N}$ and algal density in the water (Table 2) evidenced from the statistic view that $\mathrm{TN}$ and TP were the main factors that influenced the growth of algae $[15,16]$. Algal density showed a positive correlation with $\mathrm{NH}_{4}^{+}-\mathrm{N}$ in the water $(\mathrm{R}=0.63, \mathrm{p}<0.01)$, but not related to $\mathrm{NO}_{3}-\mathrm{N}$. This was probably because, compared to other nitrogen source, phytoplankton absorbed $\mathrm{NH}_{4}{ }^{+} \mathrm{N}$ in the water consume less energy [17].

The dendrogram revealed that samples were grouped into 2 defined clusters. This reason was that the band number was the higher at the Mei- 8 and Mei-10 sites, the sediment samples of Mei- 8 and Mei-10 had the higher bacterial community genetic diversity, and the concentration of TN, TP in the sediment of Mei-8 and Mei-10 was relatively high. Our CCA results also showed that TN and TP significantly influenced the bacterial community structure in the sediment, which led to Mei- 8 and Mei-10 were grouped into the cluster, and the rest of other sampling sites grouped into another cluster.

The dendrogram of bacterial communities' similarities also showed that samples were grouped into 2 defined clusters with a $60 \%$ similarity, and there were no significant variations in bacterial community structure in different sites of Meiliang Bay. This reason might be due to algal bloom and homogeneity of sediment organic fractions. First, previous research indicated that phytoplankton regimes strongly influence bacterial community composition diversity [18]. In our research, the value of algal density ranged from $0.60 \times 10^{7}$ to $1.26 \times$ 
$10^{7}$ cell /L, which were relatively high in each sampling sits. Therefore, the occurrence of strong algal bloom in Meiliang Bay might cause no significant variations in bacterial diversity between different sites. Second, the organic fractions of the sediment of the Meiliang Bay mainly derived from the suspended particulate matter of urban sewage and the organic remains of algae.

The bacterial groups we detected by sequence analysis were among the common groups found in freshwater environments [7]. In general, Proteobacteria, Acidobacteria, Cyanobacteria, Verrucomicrobia, Bacteroidetes, Actinobacteria and Firmicutes were the dominant phyla in the sediments of aquatic environments, which were also detected in other eutrophic lakes [9].

In our research, the Betaproteobacteria as the most dominant bacterial group during the period of algae bloom in the sediments of Meiliang bay was a result similar to the observation in a previous study [19]. Several studies have demonstrated that Betaproteobacteria were the dominant group in most freshwater environments, whereas Alphaproteobacteria and Gammaproteobacteria were the indigenous community in marine and Detlaproteobacteria a representative bacterial lineage in benthic environments [18]. Deltaproteobacteria could also be found in aquatic habitats or soils containing abundant organic material, and played a key role in the global carbon cycles [20]. In addition, Shao et al. reported that Epsilonproteobacteria (21.1\%) were the second dominant group of sediment bacteria in the macrophyte-dominated state, but not in the algae-dominated state. In our present study, Epsilonproteobacteria were detected in the sediment of Meiliang bay, implied that their distribution did not relate to the eutrophic levels.

Acidobacteria was the predominant phylum in the sediment of Meiliang Bay of Lake Taihu. Acidobacteria widely distributed in various environment, Such as soil, sediment, fresh water, ocean and some polluted environment [21]. They also had the ability of resistance to metal and acid and able to survive in the extreme environment [22]. Acidobacteria and Firmicutes were groups with diverse bacteria presenting capacities to degrade and transform a wide range of materials or elements $[23,24]$.

Verrucomicrobia accounted for $8.9 \%$ of the total bacterial library, which mainly distributed in the soil, and most of those bacteria were not cultured strains [25]. Zeng et al. also pointed out that Verrucomicrobia was commonly present in the sediment of Lake Xuanwu [26]. In addition, some research revealed that Verrucomicrobia were relatively more prevalent in eutrophic lakes than inoligo- or mesotrophic lakes [27]. Many Verrucomicrobia were prosthecate [28], offering them an advantage in nutrient uptake or making them more resistant to gazing [7].

Planctomycetes was aquatic bacteria with ammoxidation ability [29]. We also discovered a lot of Planctomycetes in the bacterial library of Meiliang Bay. This might be related to that Planctomycetes was a substantial component of the organic aggregates bacterial community in Lake Taihu [6].

Actinobacteria were probably one of the most abundant groups of freshwater bacterioplankton [30]. Kolmonen et al. pointed out that besides mesotrophic Lake Vesijarvi, they also have found Actinobacteria in hypereutrophic Finnish Lakes of different nutrient and humic content [27]. Haukka et al. discovered that Actinobacteria were permanent abundant members of bacterioplankton, but they did not respond strongly to the nutrient resources [7]. An experimental study also showed that Actinobacteria was the most commonly represented phylum in the bacterioplankton communities, accounting for $44.8 \%$ and $59.4 \%$ in the Meiliang Bay and East Taihu clone libraries, respectively [4].

Cyanobacterium was the major phylum in the bacterial library of Meiliang Bay. In our research, the value of algal density was relatively high, therefore, the algae death-precipitation process and hydrodynamic caused the cyanobacteria exist in the surface of sediment. Shao et al. have researched the bacterial community structure in the sediment of the macrophyte-dominated and algae-dominated areas in Lake Taihu, and discovered that Cyanobacterium was only present in the algaedominated site library [31].

\section{Conclusion}

The common occurrence of Nitrospirae in our study suggested that it was a significant group existing in sediments of eutrophic lakes. In previous reports, Nitrospirae had been found in various environments, such as sewage disposal plants, soils, freshwater aquaria, and freshwater sediments [32,33]. This organism can utilize nitrite under microaerophilic conditions. It also grows autotrophically by using nitrate as an electron acceptor under anoxic settings. In our study, Nitrospirae was commonly found at each sampling site, which was consistent with previous reports.

When compared bacterial communities in the same typical ecological areas of Lake Taihu with the previous research results, we found that there were variations in bacterial community composition between two clone libraries of Meiliang bay [19]. In total, from the sediment of Meiliang Bay, Shao et al. selected 43 representative clones in the clone libraries, by contrast, we selected 112 representative clones. Compared with our research, the results of Shao et al. revealed that Epsilonproteobacteria, Actinobacteria, Firmicutes, Nitrospirae were not found in the sediment of Meiliang Bay. Two reasons lead to the difference of two clone libraries. Firstly, it was probably because that Shao's clone library coverage was relatively insufficient. Another important reason was that the sampling sites of Shao et al. was in the mouth of Meiliang Bay, where the sediments were characteristically and frequently re-suspended by wind-wave disturbance that disrupts the water-sediment interface [3], and the bacterial community in the water column perhaps exchanged the bacterial community in the surface sediment.

Our CCA results showed that TN and TP significantly influenced the bacterial community structure in the sediment of eutrophicated Meiliang Bay, which in agreement with previous studies $[4,6,8,34]$. The nitrogen and phosphorus nutrients were used by algae and perhaps precipitated to sediment by the algal cells dead. The sediment microorganisms contributed to the release of nitrogen and phosphorus nutrients to the water column, which would be a basis for the burning of bloom when the temperature was adequate for algal growth. Undoubtedly, the transfer and transformation of nitrogen and phosphorus nutrients in the water and sediments of Meiliang bay were the consequence of bacterial activity, and influenced on bacterial community in the sediments. In Lake Taihu, TN has previously been reported to have a significant effect on the organic-aggregate-associated bacterial communities [6]. A site-specific difference of TP in Lake Taihu was identified as a driving force of the intra-habitat heterogeneity of microbial food web structure [4]. Li et al. pointed out that the number of phosphate-dissolving/decomposing bacteria was directly correlated to the total phosphorus concentration in the sediments of Guanting reservoir [34]. Furthermore, TP concentration statistically explained the differences in the bacterial community composition within 2 different drainage areas [8]. 
Citation: Wan Y, He J, Bai Y (2017) Spatial Distribution of Sediment Bacterial Communities in Eutrophicated Meiliang Bay: Correlation with Environmental Factors. J Aquac Res Development 8: 514. doi: 10.4172/2155-9546.1000514

\section{References}

1. Sinkko H, Lukkari K, Sihvonen LM, Sivonen K, Leivuori M, et al. (2013) Bacteria contribute to sediment nutrient release and reflect progressed eutrophicationdriven hypoxia in an organic-rich continental sea. PLoS One 8: 67061.

2. O'Donnell AG, Seasman M, Macrae A, Waite I, Davies JT (2001) Plants and fertilisers as drivers of change in microbial community structure and function in soils. Plant Soil 232: 135-145.

3. Qin BQ, Zhu GW, Luo LC, Gao G, Gu BH (2006) Estimation of internal nutrient release in large shallow Lake Taihu, China. Sci China Series D-Earth Sci 49 $38-50$.

4. Wu QL, Zwart G, Wu J, Kamst-van Agterveld MP, Liu S, et al. (2007) Submersed macrophytes play a key role in structuring bacterioplankton community composition in the large, shallow, subtropical Taihu Lake, China. Environ Microbiol 9: 2765-2774

5. James RT, Havens K, Zhu GW, Qin BQ (2009) Comparative analysis of nutrients, chlorophyll and transparency in two large shallow lakes (Lake Taihu, PR China and Lake Okeechobee, USA). Hydrobiologia 627: 211-231.

6. Tang XM, Gao G, Qin BQ, Zhu L, Chao J, et al. (2009) Characterization of bacterial communities associated with organic aggregates in a large, shallow, eutrophic freshwater lake (Lake Taihu, China). Microb Ecol 58: 307-322.

7. Haukka K, Heikkinen E, Kairesalo T, Karjalainen H, Sivonen K (2005) Effect of humic material on the bacterioplankton community composition in boreal lakes and mesocosms. Environ Microbiol 7: 620-630

8. Lindstrom ES, Bergstrom AK (2005) Community composition of bacterioplankton and cell transport in lakes in two different drainage areas. Aquatic Sciences 67 210-219.

9. Haller L, Tonolla M, Zopfi J, Peduzzi R, Wildi W, et al. (2011) Composition of bacterial and archaeal communities in freshwater sediments with differen contamination levels (Lake Geneva, Switzerland). Water Res 45: 1213-1228.

10. Zhou J, Bruns MA, Tiedje JM (1996) DNA recovery from soils of diverse composition. Appl Environ Microbiol 62: 316-322

11. Muyzer G, Dewaal EC, Uitterlinden AG (1993) Profiling of complex microbialpopulations by denaturing gradient gel-electrophoresis analysis of polymerase chain reaction-amplified genes-coding for 16s ribosomal-rna. Appl Environ Microbiol 59: 695-700.

12. Newton RJ, Kent AD, Triplett EW, McMahon KD (2006) Microbial community dynamics in a humic lake: Differential persistence of common freshwater phylotypes. Environ Microbiol 8: 956-970.

13. Chen YW, Qin BQ, Teubner K, Dokulil MT (2003) Long-term dynamics of phytoplankton assemblages: Microcystis-domination in Lake Taihu, a large shallow lake in China. J Plankton Res 25: 445-453.

14. Hou D, He J, Lu CW, Sun Y, Zhang F, et al. (2013) Effects of environmental factors on nutrients release at sediment-water interface and assessment of trophic status for a typical shallow lake, northwest China. Scientific World J: 716342.

15. Paerl HW, Fulton RS, Moisander PH, Dyble J (2001) Harmful freshwater algal blooms, with an emphasis on cyanobacteria. Scientific World J 1: 76-113.

16. Wang HK, Dong JD, Zhang S, Huang L (2002) Distribution of N/P ratio and its limitation to growth of phytoplankton in Sanya Bay. J tropical oceanography 21: 33-39.

17. Yang L, Zhang M, Liu ZW (2011) Uptake of various forms of nitrogen by phytoplankton community in spring in Lake Taihu. J Lake Sci 23: 605-611.
18. Eiler A, Bertilsson S (2004) Composition of freshwater bacterial communities associated with cyanobacterial blooms in four Swedish lakes. Environ Microbio 6: 1228-1243.

19. Shao KQ, Gao G, Qin BQ, Tang XM, Wang Y, et al. (2011) Comparing sediment bacterial communities in the macrophyte-dominated and algae-dominated areas of eutrophic Lake Taihu, China. Can J Microbiol 57: 263-272.

20. Rodionov DA, Dubchak I, Arkin A, Alm E, Gelfand MS (2004) Reconstruction of regulatory and metabolic pathways in metal-reducing delta-proteobacteria. Genome Biol 5: 90

21. Barns SM, Takala SL, Kuske CR (1999) Wide distribution and diversity of members of the bacterial kingdom Acidobacterium in the environment. Appl Environ Microbiol 65: 1731-1737.

22. Barns SM, Cain EC, Sommerville L, Kuske CR (2007) Acidobacteria phylum sequences in uranium-contaminated subsurface sediments greatly expand the known diversity within the phylum. Appl Environ Microbiol 73: 3113-3116.

23. Ward NL, Challacombe JF, Janssen PH, Henrissat B, Coutinho PM, et al. (2009) Three genomes from the phylum Acidobacteria provide insight into the lifestyles of these microorganisms in soils. Appl Environ Microbiol 75: 20462056

24. Goffredi SK, Orphan VJ (2010) Bacterial community shifts in taxa and diversity in response to localized organic loading in the deep sea. Environ Microbiol 12 344-363.

25. Stevenson BS, Eichorst SA, Wertz JT, Schmidt TM, Breznak JA (2004) New strategies for cultivation and detection of previously uncultured microbes. Appl Environ Microbiol 70: 4748-4755.

26. Zeng J, Yang LY, Liang Y, Li JY, Xiao L, et al. (2008) Spatial distribution of bacterial communities in sediment of a eutrophic lake revealed by denaturing gradient gel electrophoresis and multivariate analysis. Can J Microbiol 54 1053-1063.

27. Kolmonen E, Sivonen K, Rapala J, Haukka K (2004) Diversity of cyanobacteria and heterotrophic bacteria in cyanobacterial blooms in Lake Joutikas, Finland. Aquatic Microbial Ecol 36: 201-211.

28. Zwart G, Huismans R, Van Agterveld MP, Van De Peer Y, De Rijk P, et al (1998) Divergent members of the bacterial division Verrucomicrobiales in a temperate freshwater lake. Fems Microbiology Ecology 25: 159-169.

29. Costa MC, Carvalho L, Leal CD, Dias MF, Martins KL, et al. (2014) Impact of inocula and operating conditions on the microbial community structure of two anammox reactors. Environ Technol 35: 1811-1822.

30. Sekar R, Pernthaler A, Pernthaler J, Warnecke F, Posch T, et al. (2003) An improved protocol for quantification of freshwater Actinobacteria by fluorescence in situ hybridization. Appl Environ Microbiol 69: 2928-2935.

31. Shao KQ, Gao G, Wang Y, Tang XM, Qin BQ (2013) Vertical diversity of sediment bacterial communities in two different trophic states of the eutrophic Lake Taihu, China. J Environ Sci 25: 1186-1194.

32. Daims H, Nielsen PH, Nielsen JL, Juretschko S, Wagner M (2000) Nove nitrospira-like bacteria as dominant nitrite-oxidizers in biofilms from wastewater treatment plants: Diversity and in situ physiology. Water Sci Tech 41: 85-90.

33. Bartosch S, Hartwig C, Spieck E, Bock E (2002) Immunological detection of nitrospira-like bacteria in various soils. Microb Ecol 43: 26-33.

34. Li C, Yuan HL, Huang HZ (2005) Vertical distribution of phosphorus and $\mathrm{P}$-dissolving/decomposing bacteria in the sediment of Guanting reservoir. Sci China Series D-Earth Sci 48: 285-294. 